\title{
CONSERVATION TILLAGE, OPTIMAL WATER AND ORGANIC NUTRIENT SUPPLY ENHANCE SOIL MICROBIAL ACTIVITIES DURING WHEAT (TRITICUM AESTIVUM L.) CULTIVATION
}

\author{
Pankaj Sharma ${ }^{1,2}$, Geeta Singh ${ }^{2}$, Rana P.Singh*1 \\ ${ }^{1}$ Department of Environmental Science, Babasaheb Bhimrao Ambedkar University, Rae Bareily Road, Lucknow-226025, India; \\ ${ }^{2}$ Division of Microbiology, Indian Agricultural Research Institute, Pusa Road, New Delhi-110012, India.
}

Submitted: March 26, 2010; Returned to authors for corrections: April 16, 2010; Approved: November 04, 2010.

\begin{abstract}
The field experiments were conducted on sandy loam soil at New Delhi, during 2007 and 2008 to investigate the effect of conservation tillage, irrigation regimes (sub-optimal, optimal and supra-optimal water regimes), and integrated nutrient management (INM) practices on soil biological parameters in wheat cultivation. The conservation tillage soils has shown significant $(\mathrm{p}<0.05)$ increase in soil respiration $(81.1 \%)$, soil microbial biomass carbon (SMBC) (104\%) and soil dehydrogenase (DH) (59.2\%) compared to the conventional tillage soil. Optimum water supply (3-irrigations) enhanced soil respiration over sub-optimum and supra-optimum irrigations by $13.32 \%$ and $79 \%$ respectively. Soil dehydrogenase (DH) activity in optimum water regime has also increased by $23.33 \%$ and $8.18 \%$ respectively over the other two irrigation regimes. Similarly, SMBC has also increased by $12.14 \%$ and $27.17 \%$ respectively in soil with optimum water supply compared to that of sub-optimum and supra-optimum water regime fields. The maximum increase in soil microbial activities is found when sole organic source (50\% Farm Yard Manure+25\% biofertilizer+25\% Green Manure) has been used in combination with the conservation tillage and the optimum water supply. Study demonstrated that microbial activity could be regulated by tillage, water and nitrogen management in the soil in a sustainable manner.
\end{abstract}

Key words: Conservation Tillage, Integrated Nutrient Management (INM), Soil Respiration, Soil Microbial Biomass Carbon (SMBC), Dehydrogenase Activity (DH).

\section{INTRODUCTION}

India contributes approximately $12 \%(77.63 \mathrm{mt})$ of the global wheat (Triticum aestivum L.) production (12). It is an input intensive crop, grown on $13 \%$ of the cropped area in the Indo-Gangetic plains (IGP). Wheat is cultivated as a component of rice-wheat cropping system (RWCS) in IGP. The majority of Indian soils are low in $\mathrm{N}$ and therefore loading of urea $(46 \% \mathrm{~N})$ is practiced. Integrated nutrient management practices and resource conservation technologies are used to enhance crop productivity in sustainable agriculture (19). This has become more important in the wake of global climate

*Corresponding Author. Mailing address: School for Environmental Sciences, Babasaheb Bhimrao Ambedker University, Rae Bareily Road, Lucknow-226025, India.; Fax no: +91522441888, Mobile: +919889121823.; E-mail: ranapsingh1@ hotmail.com 
change which demands more judicious use of available resources. Thus, the major target in the regime of global climate change is water and energy conservation (26).

Tillage affects the physical, chemical, and biological properties of the soil (34). A proper tillage can alleviate soilrelated constraints whereas an improper tillage leads to a deterioration in soil structure. The latter further accelerated erosion, depletion of soil organic matter (SOM) and soil fertility as well as the disruption of the nutrient cycle $(15,25)$. The conservation and addition of SOM are crucial for biological, chemical and physical soil functionality and nutrient cycling particularly of $\mathrm{N}$. The $\mathrm{N}$-cycling largely depends on the microbial activities in the soil (9). The conservation tillage improves soil organic carbon (SOC) concentration, water storage and reduces soil erosion, and subsequently enhances soil quality and resilience (21). It also increases SMBC (18), activities of several soil enzymes $(20,23)$ as well as the soil respiration (40).

Microbial activities affect nutrient cycling and the availability of inorganic nutrients. The improved nutrient cycling leads to soil fertility and subsequently enhance plant growth and the crop yield (4). Soil enzymes and microbial biomass have been considered as the major indicators of soil quality due to their relationship to soil fertility, ease of measurement, and high sensitivity to changes originated by the management and environmental factors (7). Experiments have revealed a positive correlation between soil management systems and agriculturally beneficial microorganisms (17).

Many factors affect the sustainability of wheat production under the RWCS. Some important factors are SOM content, indigenous nutrient supply (14), the micronutrient, ground water, percolation (1) etc. In order to overcome these limitations and to sustain crop productivity and soil fertility, a system (multicomponent) approach involving INM practices, i.e. water conservation strategies, conservation tillage and application of organic nutrients may yield good substitute of conventional green revolution practices for wheat cropping.
Erenstein et al. (8), and Sahrawat et al. (31), have reported higher or almost equal yield for rice-wheat cropping system under conservation tillage as compared to conventional tillage. Though, an integrated approach for tillage, water and nutrient management for wheat crop has not been reported.

Therefore, experiments were undertaken to study the combined effect of integrated nitrogen application, water regimes, and tillage practices on soil (micro) biological indices during wheat cultivation.

\section{MATERIALS AND METHODS}

Experimental Location: The field experiments were conducted at the research farm of Indian Agriculture Research Institute, New Delhi, during the winter (Rabi) season of 2007 and 2008. The latitude of New Delhi is $28^{\circ} 38 \mathrm{~N}$ and longitude is $77^{\circ} 12 \mathrm{E}$ and its height above mean sea level is $216 \mathrm{~m}$.

Physical and Chemical Analysis of Soil: The top soil (0$15 \mathrm{~cm}$ ) was sandy clay-loam which was followed by a loamy lower layer $(15-90 \mathrm{~cm})$ with field capacity $19-20 \%\left(\mathrm{w} \mathrm{w}^{-1}\right)$ and permanent wilting point $7-11 \%\left(\mathrm{w} \mathrm{w}^{-1}\right)$. It had $\mathrm{pH} 7.7$, organic $\mathrm{C}$ (0.68) (16), 159-163 kg ha-1 alkaline permanganate hydrolysable $\mathrm{N}$ (37), $14 \mathrm{~kg} \mathrm{ha}^{-1} 0.5 \mathrm{~m} \mathrm{NaHCO}_{3}$ extractable P (27) and $296 \mathrm{~kg} \mathrm{ha}^{-1} 1 \mathrm{~N} \mathrm{NH}_{4} \mathrm{OAc}$ exchangeable $\mathrm{K}$ (16) determined by the procedures described by Prasad et al. (29).

Experimental Design: The experiments were laid out in split-plot design. Two main plots were divided for two tillage treatments (i.e. conservation and conventional), which were further divided in sub-plots for three different irrigation treatments (i.e. sub-optimum, optimum and supra-optimum). The sub-plots were further divided in sub-sub plots for different nutrient treatments as mentioned in Table 1. The treatments comprised of two tillage (i.e. Zero/conservation tillage and conventional tillage) were maintained in all the plots. Water management consisting of three water regimes; 2 irrigations (sub-optimal), 3- irrigation (optimal) and 5irrigations (supra-optimal) were allocated in the sub-plots (each 
at a gap of 20 days). The eight nitrogen sources applied to the wheat plots are as in Table 1.

The three replicates (i.e. $n=3$ ) were maintained for each nutrient treatment. The recommended dose of $\mathrm{N}$ in this region for wheat is $120 \mathrm{~kg} \mathrm{ha}^{-1}$ (34). The wheat cultivar (cv.) 'HD 2876' seeds were sown during the last week of October 2007 and 2008 at the spacing of $20 \times 15 \mathrm{~cm}$. A uniform dose of $33 \mathrm{~kg}$ $\mathrm{ha}^{-1} \mathrm{P}$ was made available through single superphosphate and $37 \mathrm{~kg} \mathrm{ha}^{-1}$ of $\mathrm{K}$ made available through muriate of potash. Both single superphosphate and muriate of potash applied to the plots before sowing. The chemical $\mathrm{N}$ fertilizer (urea), was applied in three split doses, i.e. half as basal dose; and the remaining two doses in two equal parts as top dressing at tillering and panicle initiation stages of wheat in the amount mentioned in Table 1. The quantity of well decomposed FYM containing 0.5 percent $\mathrm{N}$ (i.e. $0.05 \mathrm{Kg} \mathrm{N} \mathrm{Kg}^{-1}$ of FYM) on dry- weight basis was calculated by Kjeldahl's method and incorporated in the soil as a green manure (GM) before sowing. Similarly, Sesbania aculeate was applied at $10.5 \mathrm{t} \mathrm{ha}^{-1}$ before seeding of wheat. The $25 \%$ of urea as biofertilizer (Azospirillium brasilense) CDJA; received from Dr. J. Dobereiner, Brazil). The Azospirillium brasilense strain fixes $25-30 \%$ (of RDN) $\mathrm{N} \mathrm{ha-1}$. The coating of seeds with biofertilizer has been achieved by dipping the seeds in aqueous suspension culture of the biofertilizer. The inoculums density was $10^{8}$ cells $\mathrm{ml}^{-1}$ (41). A measured quantity of water through a $7.62 \mathrm{~cm}$ Parshall Flume was applied at the rate of $40 \mathrm{~mm}$ in each irrigation, as per treatment. During the crop period, a total rainfall of 112.0 and $111.8 \mathrm{~mm}$ were received during the 2007 and 2008, respectively. While relative humidity was 71 and 68.2 respectively and mean temperature was $18.24^{\circ} \mathrm{C}$ and $18.46^{\circ} \mathrm{C}$.

Table 1. Details of various nutrient combination used under integrated nutrient management practices.

\begin{tabular}{ll}
\hline Treatments / N-Source & \multicolumn{1}{c}{ Composition } \\
\hline $\mathrm{T}_{0}$ & Control \\
$\mathrm{T}_{1}$ & $\begin{array}{l}\mathrm{RDN} \text { through urea }+33 \mathrm{~kg} \mathrm{ha}^{-1} \mathrm{P} \text { added as rock phosphate, No K added } \\
\left(\mathrm{i} . \mathrm{e} . \mathrm{RDN}=120 \mathrm{~kg} \mathrm{ha}^{-1}\right)\end{array}$ \\
& $75 \% \mathrm{RDN}$ through urea $+25 \%$ RDN through farmyard manure \\
$\mathrm{T}_{2}$ & $(\mathrm{FYM})+\mathrm{PK}$ \\
& $75 \% \mathrm{RDN}$ through urea $+25 \% \mathrm{RDN}$ through green manure (GM)+PK \\
$\mathrm{T}_{3}$ & $75 \% \mathrm{RDN}$ through urea $+25 \% \mathrm{RDN}$ through biofertilizer (Azospirillium) \\
$\mathrm{T}_{4}$ & $+\mathrm{PK}$ \\
& $75 \% \mathrm{RDN}$ through urea $+25 \% \mathrm{RDN}$ through sewage sludge +PK \\
$\mathrm{T}_{5}$ & $50 \% \mathrm{RDN}$ as FYM $+25 \%$ RDN through biofertilizer $+25 \%$ RDN \\
$\mathrm{T}_{6}$ & through green manure $+\mathrm{PK}$ \\
& Blank (i.e. fallow) plot \\
$\mathrm{T}_{7}$ &
\end{tabular}

*Here T represents and respective numerals i.e. 1, $2 \ldots .7$ represents respective no. of treatments; N, represents Nitrogen, P, Phosphorus and $\mathrm{K}$, Potassium

Estimation of Soil Respiration, Dehydrogenase and Soil Microbial Biomass Carbon (SMBC): Soil samples were collected from a depth of $0-15 \mathrm{~cm}$ immediately after the harvest of wheat crop. Six sub-samples per treatment were composited. The field moist samples were sieved to $2 \mathrm{~mm}$ and analyzed for: respiration, dehydrogenase activity and microbial 
biomass carbon content in the soil. The microbial biomass carbon was estimated following chloroform fumigation extraction method (39). The soil respiration was measured by the method prescribed by Stotzky (36). The soil dehydrogenase enzyme (DH) activity was estimated by the method given by using Casida et al. (3).

Chemicals and Equipments used: All chemicals used were Sigma Chemicals, India situated in Badlapur district of Thane, Mumbai. All equipments used were of Borosil Company. Borosil is certified by ISO 9001. Manufacturing unit of Borosil is situated in Worli, Mumbai - India.

Statistical Analysis: All the data recorded were analysed by using the standard procedure of statistical analysis for splitplot design (11). Analysis of variance (ANOVA) was used to determine the effect of each treatment, when the F-ratio was significant; a multiple mean comparison was performed using C.D. (Critical Difference) (0.05 probability level) values. The data has been analysed by statistical package MSTAT.

\section{RESULTS}

\section{Soil Respiration}

The data presented in Table 2 indicate that a significant soil respiration $(81.1 \%)$ is determined in zero-tillage plots, over the conventional tillage plots. Zero tillage condition has brought about significant soil respiration compared to conventional tillage. Among the integrated nitrogen management treatments, the highest rate of soil respiration was recorded in treatments where the $\mathrm{N}$ requirement has been made available through a sole organic source (of $\mathrm{N}$ ) (i.e. $\mathrm{T}_{6}$ ) (i.e. $32.72 \mathrm{mg} \mathrm{CO}_{2}(100 \mathrm{~g})^{-1}$ soil) followed by the treatment $\mathrm{T}_{5}$ (i.e. $32.22 \mathrm{mg} \mathrm{CO}_{2}(100 \mathrm{~g})^{-1}$ soil. These values showed significant $(\mathrm{p}<0.05)$ soil respiration as compared to the control plots. For a given nutrient management practice, the three different water regimes significantly affected the soil respiration activity. Soil receiving sole organic source during 3-irrigation recorded $10.3 \%$ and $23.7 \%$ higher soil respiration compared to 2- irrigation and 5- irrigation respectively (Table 3). The use of urea as a sole $\mathrm{N}$-source brought about a decrease of $38.87 \%$ and $32.28 \%$ in soil respiration under 2- irrigation and 5irrigation respectively, compared to 3- irrigation. The substitution of sewage sludge for $25 \%$ RDN showed statistically identical value of soil respiration under 2irrigation and the 5- irrigation but significantly higher soil respiration in plots with 3-irrigation.

The most important parameter influencing the soil respiration has been tillage regime, however, the treatment where the sole organic source has been used as N-source along with optimum irrigation provide better results as compared to other nutrient treatments and irrigation regimes respectively.

\section{Soil Dehydrogenase Activity (DH)}

The zero tillage (conservation tillage) soil has brought about significant soil dehydrogenase activity i.e.59.2\% compared to the conventional tillage soil in the wheat fields of IGP (Table 2). The frequency of irrigation has also affected soil dehydrogenase activity. The maximum soil dehydrogenase activity (1.85 $\mu \mathrm{g}$ TPF $\mathrm{g}^{-1}$ soil $\left.\mathrm{h}^{-1}\right)$ has been observed in 3irrigation plots, followed by 5 - irrigation $\left(1.71 \mu \mathrm{g} \mathrm{TPF}^{-1}\right.$ soil $\mathrm{h}^{-1}$ ) and 2- irrigation (1.50 $\mu \mathrm{g}$ TPF $\mathrm{g}^{-1}$ soil $\mathrm{h}^{-1}$ ) plots (Table 4). Among the nutrient treatment sole organic source is found to be most effective. It brought about $12.5 \%$ increases in dehydrogenase activity compared to control. The next higher value has been observed with $\mathrm{T}_{5}$ treatment (Table 2). Other plots having RDN in various forms also had higher soil dehydrogenase activity compared to control plots. The conservation tillage plots with 3-irrigations have brought about significantly higher soil dehydrogenase activity over the conventional tillage plots in all the studies (Table 4). The maximum soil DH has been, however, observed in the plots applied with conservation tillage, 3- irrigation and sole $\mathrm{N}$ supply through the organic sources i.e. FYM + biofertilizer + GM which were closely followed when $75 \% \mathrm{~N}$ was urea and $25 \%$ as biofertilizer. 
Integrated nutrient treatments, where the RDN has been substituted with sole organic source under zero tillage registered $74.9 \%$ increase in DH activity compared to conventional tillage system. While treatments where at least $25 \%$ of RDN has been substituted with FYM or biofertilizer under zero tillage system registered $106.3 \%$ and $87.6 \%$ increase respectively, compared to conventional tillage system (Table 4). The 2- irrigation and 5- irrigation has been slightly less favorable for enzyme activity as it resulted in a decrease of DH activity by $23.3 \%$ and $8.2 \%$, respectively, compared to 3 irrigation. In contrast, the treatments where urea has been used as sole $\mathrm{N}$-source $\left(\mathrm{T}_{1}\right)$ or where $75 \%$ urea+25\% FYM $\left(\mathrm{T}_{2}\right)$ is applied, DH activity is found to be lower in case of 3irrigation as compared to 2- irrigation and 5- irrigation. Similar, results have been obtained under remaining organic treatments where 3- irrigations brought about better $\mathrm{DH}$ activities than 2-irrigation and 5- irrigations.

The most important parameter influencing the soil DH activity has been tillage regime. However, the treatment where the sole organic source has been used as N-source along with 3 - irrigation provide better results as compared to other nutrient treatments and irrigation regimes respectively. Here some variations are obtained for 2- irrigation and 5- irrigation regimes, where $75 \%$ urea+25\% FYM treatment yielded slightly better results than sole organic $\mathrm{N}$-source.

\section{Soil Microbial Biomass Carbon}

The zero tillage soil supported higher (104\%) soil microbial biomass carbon (SMBC) than the conventional tillage soil (Table 2). The soils subjected to the 3 -irrigation has shown the $12.14 \%$ and $27.17 \%$ higher SMBC than the 2irrigation and 5- irrigation treatments, respectively. Significant variations in SMBC were recorded among different INM treatments as highest SMBC recorded in treatment $\mathrm{T}_{6}$ followed by $\mathrm{T}_{5}$ and then $\mathrm{T}_{2}$. Application of RDN as organic sources has resulted in an increase of SMBC by $71.3 \%$ and $48.12 \%$ compared to control and $\mathrm{RDN}$ (as urea), respectively. However, Treatment $T_{3} \& T_{4}$ have produced little effect in improving SMBC under zero tillage wheat soils. This may be due to the low redox conditions existing under zero tillage soils. The partial or complete substitution of the RDN by organic sources favored SMBC significantly in zero tillage soils compared to conventional tillage soil. The magnitude of increase recorded under conventional tillage soil with sole organic source (123.34\%), sewage sludge (111.54\%), FYM (103.07\%), GM (95.99\%), and biofertilizer (92.9\%) compared to the corresponding conventional tillage treatments (Table 5).

For a given $\mathrm{N}$ management treatment, the irrigation treatments played a significant role in determining SMBC status. The sole organic source substitution has shown the highest (333.18 $\mathrm{mg} \mathrm{C} \mathrm{g}^{-1}$ soil) (Table 5) SMBC at 3- irrigation. The 3-irrigation as a whole has shown highest SMBC values under all treatments applied followed by 2 - irrigation and then 5- irrigation. Thus among the three different water regimes 3irrigation supported significantly higher SMBC than 2irrigation and 5-irrigation. The magnitude of decrease has been $10.37 \%$ and $14.79 \%$ for RDN through urea, $8.39 \%$ and $13.1 \%$ for RDN as FYM, 5.6\% and $10.78 \%$ for RDN as GM, $22.56 \%$ and $56.19 \%$ for RDN as biofertilizer, $12.14 \%$ and $27.17 \%$ for sole organic N source, $2.57 \%$ and $17.12 \%$ for sewage- sludge and $6.19 \%$ and $22.35 \%$ for blank plot for 2- irrigation and 5irrigation, respectively compared to 3-irrigation.

The most important parameter influencing the SMBC activity is tillage regime. However, the treatment where the sole organic source has been used as N-source along with optimum irrigation provide better results as compared to other nutrient treatments and irrigation regimes respectively. 
Table 2. Effects of tillage, water regimes and integrated $\mathrm{N}$ management practices on soil biological properties in wheat cultivated under the contrasting agronomic practices.

\begin{tabular}{|c|c|c|c|}
\hline Treatments & $\begin{array}{c}\text { Soil respiration } \\
\left(\mathrm{mg} \mathrm{CO}_{2}(100 \mathrm{~g})^{-1} \text { soil }\right. \\
\left.\text { per } \mathrm{h}^{-1}\right) \\
\end{array}$ & $\begin{array}{c}\text { Soil dehydrogenase } \\
\text { activity }\left(\mu \mathrm{g} \text { TPF } \mathrm{g}^{-1} \text { soil }\right. \\
\left.\operatorname{per} \mathrm{h}^{-1}\right)\end{array}$ & $\begin{array}{c}\text { Microbial } \\
\text { biomass carbon } \\
\left(\mu \mathrm{g} \mathrm{g}^{-1} \text { soil }\right) \\
\end{array}$ \\
\hline \multicolumn{4}{|l|}{ Tillage (T) } \\
\hline Conservation tillage & 36.60 & 2.07 & 163.67 \\
\hline Conventional tillage & 20.21 & 1.30 & 80.23 \\
\hline C.D. $(0.05)$ & 0.85 & 0.09 & 1.69 \\
\hline \multicolumn{4}{|l|}{ Water management (WM) } \\
\hline 2-irrigation (Sub-optimal) & 27.32 & 1.50 & 121.82 \\
\hline 3-irrigation (Optimum) & 30.96 & 1.85 & 136.61 \\
\hline 5-irrigation (Supra-optimum) & 26.95 & 1.71 & 107.42 \\
\hline C.D. $(0.05)$ & 1.04 & 0.11 & 2.08 \\
\hline Tillage $\times \mathrm{WM}(\mathrm{T} \times \mathrm{WM})$ & $*$ & $*$ & $*$ \\
\hline \multicolumn{4}{|l|}{ INM } \\
\hline 1. Control & 25.52 & 1.175 & 99.76 \\
\hline 2. RDN through urea & 30.96 & 1.955 & 115.41 \\
\hline $\begin{array}{l}\text { 3. } 75 \% \text { RDN through urea }+25 \% \text { RDN } \\
\text { through farmyard manure }(\mathrm{FYM})\end{array}$ & 30.62 & 1.96 & 129.76 \\
\hline $\begin{array}{l}\text { 4. } 75 \% \text { RDN through urea }+25 \% \mathrm{RDN} \\
\text { through green manure }(\mathrm{GM})\end{array}$ & 25.86 & 1.33 & 107.82 \\
\hline $\begin{array}{l}\text { 5. } 75 \% \text { RDN through urea }+25 \% \text { through } \\
\text { Biofertilizer }\end{array}$ & 32.22 & 2.10 & 146.49 \\
\hline $\begin{array}{l}\text { 6. } 75 \% \text { RDN through urea }+25 \% \mathrm{RDN} \\
\text { through sewage sludge }\end{array}$ & 25.19 & 1.31 & 108.01 \\
\hline $\begin{array}{l}\text { 7. } 50 \% \mathrm{RDN} \text { as FYM }+25 \% \mathrm{RDN} \text { through } \\
\text { biofertilizer }+25 \% \mathrm{RDN} \text { through green } \\
\text { manure }\end{array}$ & 32.72 & 2.144 & 170.95 \\
\hline 8. Blank plot & 24.21 & 1.191 & 97.32 \\
\hline \multicolumn{4}{|l|}{ CD (0.05) } \\
\hline $\mathrm{T} \times \mathrm{INM}$ & $*$ & $*$ & $*$ \\
\hline $\mathrm{WM} \times \mathrm{INM}$ & $*$ & $*$ & $*$ \\
\hline $\mathrm{T} \times \mathrm{WM} \times \mathrm{INM}$ & $*$ & $*$ & $*$ \\
\hline
\end{tabular}

RDN, Recommended dose of nitrogen; *significant; values of conservation \& conventional tillage are mean of respective tillage values, irrespective of water \& nutrient treatments. Similarly, values for water management \& nutrient management are mean of respective parameters of the other two. CD represents critical differences. Values are statistically significant. Data analyzed by one way ANOVA at LSD $<0.05$. 


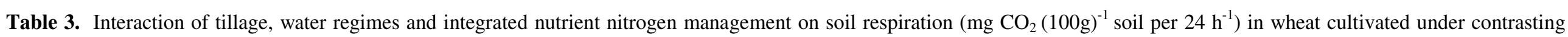
agronomic practices.

\begin{tabular}{|c|c|c|c|c|c|c|c|c|}
\hline \multirow[b]{4}{*}{ Treatments } & \multicolumn{7}{|c|}{ Tillage } & \multirow[b]{4}{*}{ Mean } \\
\hline & \multirow{2}{*}{\multicolumn{2}{|c|}{ Conservation Tillage }} & \multirow[t]{2}{*}{ Conventional Tillage } & \multirow{2}{*}{\multicolumn{4}{|c|}{ Conventional Tillage }} & \\
\hline & & & & & & & & \\
\hline & $\begin{array}{c}\text { 2- } \\
\text { irrigation } \\
\text { (sub-optimal) }\end{array}$ & $\begin{array}{c}\text { 3- } \\
\text { irrigation } \\
\text { (optimum) }\end{array}$ & $\begin{array}{l}\text { 5-irrigation } \\
\text { (supra- } \\
\text { optimal) }\end{array}$ & Mean & $\begin{array}{c}2- \\
\text { irrigation } \\
\text { (sub-optimal) }\end{array}$ & $\begin{array}{c}\text { 3- } \\
\text { irrigation } \\
\text { (optimum) }\end{array}$ & $\begin{array}{l}\text { 5-irrigation } \\
\text { (supra- } \\
\text { optimal) }\end{array}$ & \\
\hline Control & 33.220 & 34.760 & 30.300 & 32.76 & 18.410 & 19.210 & 17.220 & 18.28 \\
\hline RDN through urea & 34.047 & 47.280 & 35.740 & 39.02 & 20.327 & 22.270 & 26.110 & 22.90 \\
\hline $\begin{array}{l}75 \% \text { RDN through urea }+25 \% \text { RDN } \\
\text { through farmyard manure (FYM) }\end{array}$ & 40.700 & 42.020 & 36.120 & 39.61 & 22.340 & 24.140 & 18.380 & 21.62 \\
\hline $\begin{array}{l}75 \% \text { RDN through urea }+25 \% \text { RDN } \\
\text { through green manure }(\mathrm{GM})\end{array}$ & 31.580 & 34.100 & 31.860 & 32.51 & 19.240 & 21.110 & 17.260 & 19.20 \\
\hline $\begin{array}{l}75 \% \text { RDN through urea }+25 \% \\
\text { through biofertilizer }\end{array}$ & 35.227 & 47.080 & 40.760 & 41.02 & 20.680 & 26.840 & 22.700 & 23.41 \\
\hline $\begin{array}{l}75 \% \text { RDN through urea }+25 \% \text { RDN } \\
\text { through sewage sludge }\end{array}$ & 31.260 & 33.380 & 31.900 & 32.18 & 17.080 & 22.040 & 15.440 & 18.19 \\
\hline $\begin{array}{l}50 \% \mathrm{RDN} \text { as FYM }+25 \% \mathrm{RDN} \\
\text { through biofertilizer }+25 \% \mathrm{RDN} \\
\text { through green manure }\end{array}$ & 43.900 & 48.430 & 39.160 & 43.83 & 24.700 & 21.123 & 19.020 & 21.61 \\
\hline Blank Plot & 28.687 & 34.540 & 32.620 & 31.95 & 15.710 & 17.100 & 16.560 & 16.46 \\
\hline Mean & 34.83 & 40.19 & 34.80 & & 19.81 & 21.73 & 19.09 & \\
\hline C.D. $(0.05)$ & $\begin{array}{l}\text { Tillag } \\
\text { Tillag } \\
\text { Tillag }\end{array}$ & $\begin{array}{l}\times \text { Water Reg } \\
\times \text { Nutrient } M \\
\times \text { Nutrient } \mathrm{N}\end{array}$ & $\begin{array}{l}\text { ne }= \\
\text { nagement }= \\
\text { nagement }=\end{array}$ & $\begin{array}{l}0.073 \\
0.121 \\
0.140\end{array}$ & & & & \\
\hline
\end{tabular}




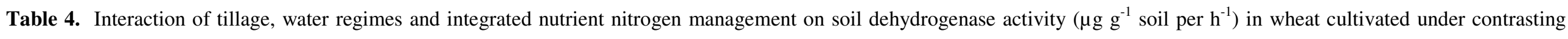
agronomic practices.

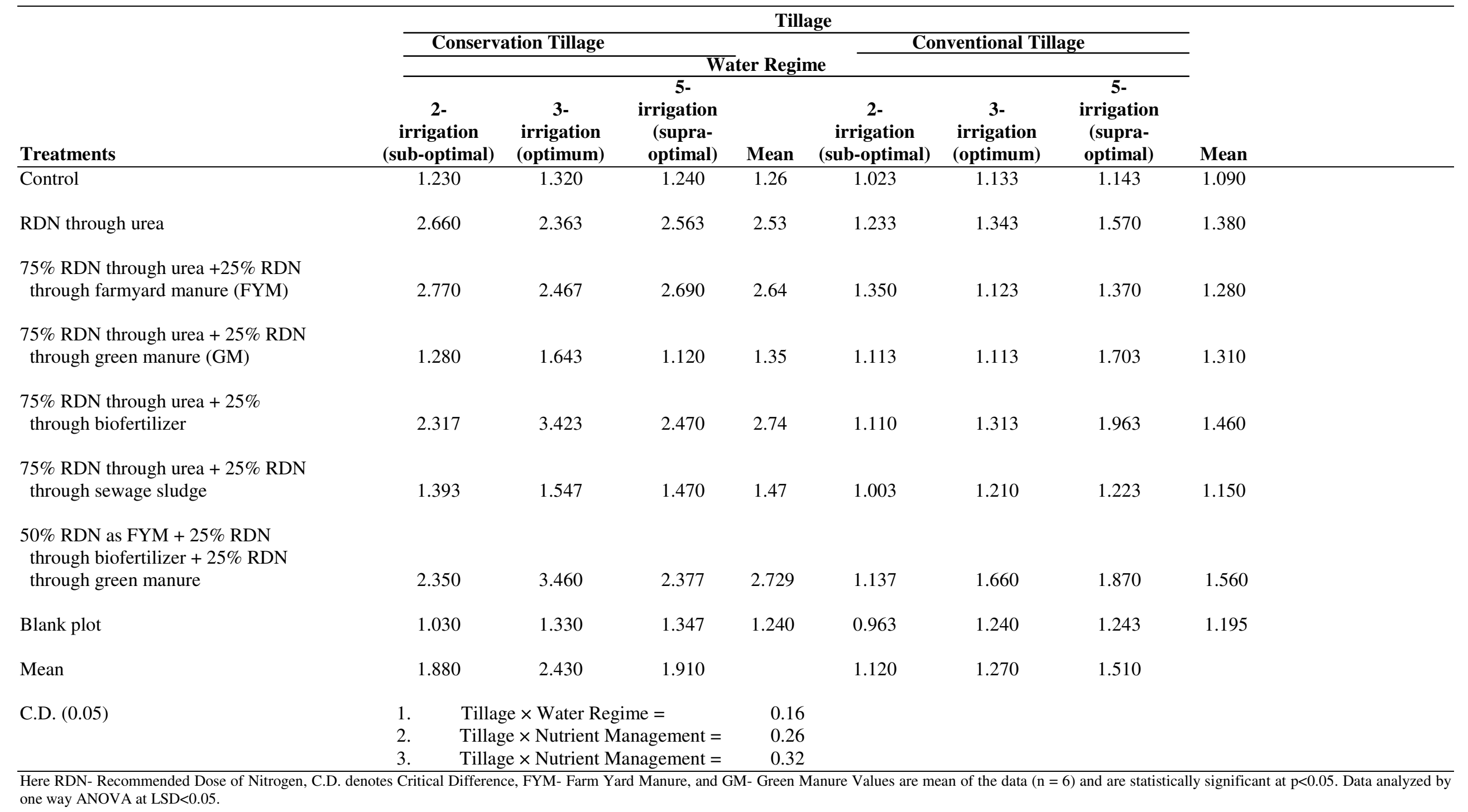




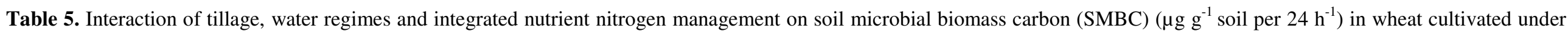
contrasting agronomic practices.

\begin{tabular}{|c|c|c|c|c|c|c|c|c|}
\hline \multirow[b]{4}{*}{ Treatments } & \multicolumn{7}{|c|}{ Tillage } & \multirow[b]{4}{*}{ Mean } \\
\hline & \multirow{2}{*}{\multicolumn{2}{|c|}{ Conservation Tillage }} & \multirow{2}{*}{\multicolumn{2}{|c|}{ Conventional Tillage }} & \multirow{2}{*}{\multicolumn{3}{|c|}{ Conventional Tillage }} & \\
\hline & & & & & & & & \\
\hline & $\begin{array}{c}2- \\
\text { irrigation } \\
\text { (sub-optimal) }\end{array}$ & $\begin{array}{c}\text { 3- } \\
\text { irrigation } \\
\text { (optimum) }\end{array}$ & $\begin{array}{l}\text { 5- } \\
\text { irrigation } \\
\text { (supra- } \\
\text { optimal) }\end{array}$ & Mean & $\begin{array}{c}2- \\
\text { irrigation } \\
\text { (sub-optimal) }\end{array}$ & $\begin{array}{c}\text { 3- } \\
\text { irrigation } \\
\text { (optimum) }\end{array}$ & $\begin{array}{l}\text { 5- } \\
\text { irrigation } \\
\text { (supra- } \\
\text { optimal) }\end{array}$ & \\
\hline Control & 130.440 & 139.310 & 122.220 & 130.66 & 66.620 & 76.670 & 63.330 & 68.81 \\
\hline RDN through urea & 152.630 & 168.470 & 146.760 & 185.95 & 72.910 & 80.140 & 71.570 & 74.87 \\
\hline $\begin{array}{l}75 \% \text { RDN through urea }+25 \% \mathrm{RDN} \\
\text { through farmyard manure (FYM) }\end{array}$ & 171.470 & 185.860 & 164.330 & 173.89 & 93.360 & 85.110 & 78.410 & 88.63 \\
\hline $\begin{array}{l}75 \% \text { RDN through urea }+25 \% \text { RDN } \\
\text { through green manure }(\mathrm{GM})\end{array}$ & 142.330 & 150.330 & 135.690 & 142.78 & 75.110 & 69.270 & 74.170 & 72.85 \\
\hline $\begin{array}{l}75 \% \text { RDN through urea }+25 \% \\
\text { through biofertilizer }\end{array}$ & 192.300 & 235.690 & 150.890 & 192.96 & 110.980 & 103.890 & 85.220 & 100.03 \\
\hline $\begin{array}{l}75 \% \text { RDN through urea }+25 \% \text { RDN } \\
\text { through sewage sludge }\end{array}$ & 151.660 & 155.560 & 132.817 & 146.68 & 70.430 & 74.150 & 63.430 & 69.34 \\
\hline $\begin{array}{l}50 \% \mathrm{RDN} \text { as } \mathrm{FYM}+25 \% \mathrm{RDN} \\
\text { through biofertilizer }+25 \% \mathrm{RDN} \\
\text { through green manure }\end{array}$ & 201.670 & 335.180 & 171.690 & 236.16 & 121.690 & 113.780 & 81.760 & 105.74 \\
\hline Blank plot & 133.410 & 141.670 & 115.790 & 130.29 & 62.220 & 70.640 & 60.210 & 64.36 \\
\hline Mean & 159.480 & 189.010 & 142.520 & & 84.160 & 84.210 & 72.330 & \\
\hline C.D. (0.05) & \multicolumn{3}{|c|}{$\begin{array}{l}\text { Tillage } \times \text { Water Regime }= \\
\text { Tillage } \times \text { Nutrient Management }= \\
\text { Tillage } \times \text { Nutrient Management }=\end{array}$} & $\begin{array}{l}2.94 \\
4.81 \\
5.88\end{array}$ & & & & \\
\hline
\end{tabular}

one way ANOVA at $\mathrm{LSD}<0.05$. 


\section{DISCUSSION}

The data presented in table 2 to 5 indicate that the conservation tillage (i.e. zero/no-tillage) increases soil microbial activity in terms of soil respiration, soil $\mathrm{DH}$ and SMBC. The soil microbial activities have shown a positive synergistic effect of conservation tillage with 3- irrigation (at the gap of 20 days) for the wheat cultivation. Various nutrient treatments (i.e. inorganic form as well as organic form) also affect the soil microbial properties in tillage and irrigation treatments (34).

Higher soil microbial activities are indicative of enhanced soil fertility. It has been reported in many crop fields in various agro-climatic conditions during the conservation tillage (38). Masto et.al., 2006 (23) and Sahrawat et.al., 2010 (31) have reported that the increased microbial activity. The increased microbial activity enhance crop productivity and yield as well as better soil fertility in different agro-climatic conditions under conservation tillage system in wheat field.।

Daughtry et al. (5), reported increased biodegradation of biomass under conservation tillage in wheat fields. Martinez et al. (22) reported improved long-term soil microbial community and enzymatic activity responses to an integrated cropping and livestock system. However, no report is available to our data base which has reported high microbial activity in wheat fields in IGP under tillage management, various water regimes and different INM practices which include various organic supplements.

The excessive water, on the other hand can harm soil microbes and plant growth. It produces anaerobic conditions in rhizosphere and produces conditions like hypoxia (a condition of oxygen deficiency). The hypoxic condition inhibits reproductive growth of plants and thus delays harvest time. This condition reduces yield of plant to almost zero (13). Wheat suffers badly, if excessive amount of water is available to the plant rhizosphere (30). Therefore, it is essential to optimize water requirements for higher microbial activity, which may further lead to the improved soil fertility and the crop productivity.

The Irrigation regimes have also significantly affected microbial activities of rhizosphere (34). Our results indicate that 3-irrigations (each after 20 days) is sufficient to maintain higher soil microbial activity. But an increase in frequency of irrigation causes reduction in soil microbial activity. Thus, a double loss of crop yield and water (under excessive irrigation) occurs. Simultaneously, reduced irrigation (i.e. 2-irrigations) also causes a slight drop in values of soil microbiological parameters (Table 2 to 5 ).

Davis et al. (6), have reported that soil microbial communities play an important role in agroecosystem functioning on a large scale and they also contribute to global element cycling. The rhizosphere of plants contributes significantly to biogeochemical cycles (circulation of elements like $\mathrm{C}, \mathrm{N}, \mathrm{P}, \mathrm{S}$ etc.) in biosphere. Biogeochemical cycles are important for maintaining ecological balance and nutrient availability (24). It has been observed that no-tillage practices increases availability of soil enzymes like acid phosphatase, amylase, cellulase etc. Thus, no-tillage practices help in circulation of minerals which enhances total carbon $(C)$ and $\mathrm{N}$ availability to plants (2). Our results also support that increased microbial activity and thus improved nutrient availability help in circulation of minerals (table 4 and 5).

Indian soil of IGP region which is used for extensive agricultural practices are deficient in $\mathrm{N}$. Therefore, the plants especially cereals like wheat are highly responsive to the exogenously supplied N-fertilizers (28). The excessive Nloading in extensive agricultural practices enhances the input cost of agriculture on one hand and causes nutrient losses in the form of leaching, run-off and volatilization $(33,35)$. It has been considered opinion that inorganic $\mathrm{N}$-fertilizers should be replaced by organic forms e.g., FYM, GMs and biofertilizers etc. by maintaining the crop productivity as much as possible. This approach is considered as INM (31).

It indicate that INM practices, specially, replacement or 
substitution of inorganic sources with organic sources, (where $25-50 \%$ recommended dose of urea has been replaced by organic manures like FYM, biofertilizer (Azospirillium) and green manures) maintain highest soil respiration, soil DH and SMBC (Table 2 to 5) during wheat cultivation. Similar results have been reported by Hossain M.A., 2009 (14) and singh et.al., 2008 (34) in various cereals. However, studies are very rare in which the soil microbial activities under different $\mathrm{N}$ nutrition including wheat have been correlated to water regimes and tillage practices, especially in IGP region.

\section{CONCLUSIONS}

The studies presented in this paper suggest that higher soil fertility in terms of soil microbial activity can be maintained in IGP having pre-dominantly the rice-wheat cropping system by using zero tillage as conservation tillage practice, optimal irrigation i.e. 3-irrigation at interval of 20 days. Further, either sole organic (FYM: Biofertilizer: GM (2:1:1)) or a combination of organic and inorganic $\mathrm{N}$-applications in ratio of $1: 1$ can be used with above stated tillage and irrigation practices to save energy, water, cost of cultivation and to maintain high productivity of crops in an ecologically balanced manner.

\section{REFERENCES}

1. Arora, V.K.; Gajri, P.R.; Uppal, H.S. (2006). Pudding, irrigation, and transplanting time effects on productivity of rice-wheat system on a sandy loam soil of Punjab, India. Soil Till Res. 85:212-220.

2. Balota, E.L.; Kanashiro, M.; Filho, A.C.; Andrade, D.S.; Dick, R.P. (2004). Soil enzyme activities under long-term tillage and crop rotation systems in subtropical Agro-Ecosystems. Braz. J. Microbiol. 35:300-306.

3. Casida, L.E.Jr.; Klein, D.A.; Santoro, T. (1964). Soil dehydrogenase activity. Soil Sci. 98:371-376

4. Crecchio, C.; Curci, M.; Antonella, P.; Ricciuti, P.; Tursi, N.; Ruggiero, P. (2007). Soil microbial dynamics and genetic diversity in soil under mono culture wheat grown in different long term management systems. Soil Biol Biochem. 39:1391-1400.

5. Daughtry, C.S.; Serbin, G.; Reeves III, J.B.; Doraiswamy, P.C.; Hunt Jr., R. (2010). Spectral reflectance of wheat residue during decomposition and remotely sensed estimates of residue cover. Remote Sens. 2:416-431.

6. Davis, S.C.; Parton, W.J.; Dohleman, F.G.; Smith, C.M. (2010) Comparative biogeochemical cycles of bioenergy crops reveal Nitrogenfixation and low greenhouse gas emission in a Miscanthus $\mathrm{x}$ giganteus agro-ecosystems. Ecosystem. 13:144-156.

7. Diosma, G.; Aulicino, M.; Chidichimo, H.; Balatti, P.A. (2006). Effect of tillage and $\mathrm{N}$ fertilization on microbial physiological profile of soil cultivated with wheat. Soil Till Res. 91:236-243.

8. Erenstein, O.; Farooq, U.; Malik, R.K.; Sharif, M. (2008). On-farm impacts of zero-tillage wheat in South-Asia's rice-wheat systems. Field Crops Res.105(3): 240-252.

9. Fornara, D.A.; Tilman, D. (2009). Ecological mechanisms associated with the positive diversity-productivity relationship in and $\mathrm{N}$-limited grassland. Ecology: vol. 90, No. 2, pp. 408-418.

10. Gill, M.S.; Shukla, A.K.; Singh, M.P.; Tomar, O.K.; Kumar, R.; Majumdar, K.; Tiwari, K.N. (2009). Evaluation of nutrient management options for yield, economics and nutrient use efficiency. Better CropsIndia/2009:12-15.

11. Gomez K.A.; Gomez A.A. (1985). Statistical procedures for agricultural research. New York: John Wiley and Sons.

12. Government of India, New Delhi. (2009). Economic Survey 2008-2009. Agriculture. Economic Division. Government of India. New Delhi: Ministry of Finance. p. 154-173.

13. Guo, S.; Tang, Y.; Gao, F.; Ai, W.; Qin, L. (2008). Effects of low pressure and hypoxia on growth and development of wheat. Acta Astronautica. 63(7-10):1081-1085.

14. Hossain, M.A. (2009). Nutrient and residue management for improving productivity and $\mathrm{N}$ use efficiency of rice-wheat-mungbean systems in Bangladesh. The Proceedings of the International Plant Nutrition Colloquium XVI

15. Jacinthe, P.A.; Lal, R. (2009). Tillage Effects on Carbon Sequestration and Microbial Biomass in Reclaimed Farmland Soils of Southwestern Indiana. Soil Sci Soc. Am. J. 73:605-613.

16. Jackson, M.L. (1973). Soil chemical analysis. New Delhi: Practice Hall of India Pvt. Ltd.

17. Kaschuk, G.; Hungria, M.; Santos, J.C.P.; Berton-Junior, J.F. (2006). Differences in common bean rhizobial associated with soil tillage management in Southern Brazil. Soil Till Res. 87:205-217.

18. Liu, E.K.; Zhao, B.Q.; Mei, X.R.; So, H.B.; Li, J.; Li, X.Y. (2009). Effects of no-tillage management on soil biochemical characteristics in northern China. The Jour. Agri. Sci. Published online by Cambridge university press (20/11/2009). doi 10.1017/S0021859609990463.

19. Liu, X.; Liu, J.; Xing, B.; Herbert, S.J.; Meng, K.H.; Xiaozeng, H.; Zhang, X. (2005). Effect of long term continuous cropping, tillage and fertilization on soil organic carbon and nitrogen of black soils in China. Comm. Soil Sci plant Anal. 36:1229-1239. 
20. Lupwayi, N.Z.; Hanson, K.G.; Harker, K.N.; Clayton, G.W.; Blackshaw, R.E.; O’Donovan J.T.; Johnson, E.N.; Gan, Y.; Irvine, R.B.; Monreal, M.A. (2007). Soil microbial biomass, functional diversity and enzyme activity in glyphosate-resistant wheat-canola rotations under lowdisturbance direct seeding and conventional tillage Soil Biol Biochem. 39:1418-1427.

21. Madejon, E.; Moreno, F.; Murillo, J.M.; Pelegrin, F. (2007). Soil biochemical response to long-term conservation tillage under semi-arid. Mediterranean conditions. Soil Till Res. 94:346-352.

22. Martinez, V.A.; Bell, C.W.; Morris, B.E.L.; Zak, J.; Allen, V.G. (2010), Long-term soil microbial community and enzymatic activity responses to an integrated cropping-livestock system in a semi-arid region. Agric. Ecosyst. Env. (2010), doi:10.1016/j.agee.2010.02.008.

23. Masto, R.E.; Chhonkar, P.K.; Singh, D.; Patra, A.K. (2006). Changes in soil biological and biochemical characteristics in a long-term field trial on a subtropical inceptisol. Soil Biol Biochem. 38:1577-1582.

24. McGroddy, M.E.; Daufresne, T.; Hedin, L.O. (2004). Scaling of C:N:P stoichiometry in forests worldwide: Implications of terrestrial red-field type ratios. Ecology. 85(9):2390-2401.

25. Mohanty, M.; Painuli, D.K.; Misra, A.K.; Ghosh, P.K. (2007). Soil quality effects of tillage and residue under rice-wheat cropping on a vertisol in India. Soil Till Res. 92:243-250.

26. Nhemachena, C.; Hasran, R. (2007): Micro Level Analysis to Climate Change in Southern Africa, IFPRI. Discussion Paper No.714 (Washington, DC: International Food Policy Research Institute).

27. Olsen, C.R.; Cole, C.V.; Wantanable F.S.; Dean L.A. (1954). Estimation of available $\mathrm{P}$ in soil by extraction with sodium bicarbonate. USDA Circ. No. 939. Washington. p.19.

28. Pal, D.K.; Bhattachary, T.; Srivastava, P.; Chandran, P.; Ray, S.K. (2009). Soils of the Indo-Gangetic plains:their historical perspective and management. Curr. Sci. 96:1193-1202.

29. Prasad, R.; Shivay, Y.S.; Kumar, D.; Sharma, S.N. (2006). Learning by doing in soil fertility (A practical manual for soil fertility). New Delhi: division of agronomy, Indian Agricultural Research Institute. p. 68.

30. Prasad, R.; Nagarajan, S. (2004): Rice-Wheat Cropping system-Food security and sustainability. Curr. Sci. (87):1334-35.
31. Sahrawat, Y.S.; Singh, B.; Malik, R.K.; Ladha, J.K.; Gathala, M.; Jat, M.L. (2010). Evaluation of alternative tillage and crop establishment methods in a rice-wheat rotation in North-Western IGP. Field Crops Res. 116(3):260-267.

32. Simon, T.; Javurek, M.; Mikanova, O.; Vach, M. (2009). The influence of tillage systems on soil organic matter and soil organic matter and soil hydrophobicity. Soil Till. Res. 105:44-48.

33. Singh, B.; Singh, Y. (2008). Reactive nitrogen in Indian Agriculture: Inputs, use efficiency and leakages. Curr. Sci. 94:1382-1393.

34. Singh, G.; Kumar, D. (2008); Influence of tillage, water regimes and integrated nitrogen management practices on soil quality indices in rice (Oryza sativa L.) in the Indo-Gangetic plains; Archives of Agronomy and Soil Science 00:1-12.

35. Singh, R.P.; Dahiya, S.; Jaiwal, P.K. (2006). Slow release fertilizers for sustained nitrogen supply and high plant productivity. In: Nitrogen Nutrition in Plant Productivity (Eds. Singh RP, Shankar N and Jaiwal PK), Stadium Press, LLC, houston, USA, pp:329-349.

36. Stotzky, G. (1965). Microbial respiration. In: Blank CA, editor. Method of soil analysis. Part 2. Madison (WI): American Society of Agronomy Inc.

37. Subbiah, B.V.; Asija, G.L. (1956). A rapid procedure for estimation of available nitrogen in soils. Curr Sci. 5:656-659.

38. Valarini, P.J.; Alvarez, M.C.D.; Gasco, J.M.; Guerrero, F.; Tokeshi, H. (2002). Integrated evaluation of soil quality after the incorporation of organic matter and microorganisms. Braz. J. Microbiol. 33(2): doi: 10.1590/51517-83822002000100007.

39. Vance, F.; Brookes, P.; Jenkinson, D. (1987). Microbial biomass measurements in forest soil: the use of the chloroform fumigation incubation method in strongly acid soils. Soil Biol Biochem. 19:697-702.

40. Zhang, X.P.; Fang, H.J.; Yang, X. (2005). No-till and hand hoeing impacts on carbon dioxide emissions from a silt loam in Northeast China. Comm. Soil Sci Plant Anal. 36:1041-1045.

41. Zorita, M.D.; Canigia, M.V.F. (2008): Field performance of a liquid formulation of Azospirillium brasilense on dryland wheat productivity. Eur. J. Soil Biol., 45 (1):3-11. 